\title{
Türkiye Türkçesinde Antropometri Sistemiyle Oluşturulan Ölçü Birimlerinin Anlamsal Açıdan Bir Değerlendirmesi
}

\author{
Umay ÇAKIR \\ Kırşehir Ahi Evran Üniversitesi \\ umay.cakir@ahievran.edu.tr \\ ORCID ID: 0000-0002-9051-3605
}

\begin{tabular}{lrr} 
Araştırma Makalesi & DOI: $10.31592 /$ aeusbed.675698 \\
\hline Geliş Tarihi: 16.01 .2020 & Revize Tarihi: 02.07.2020 & Kabul Tarihi: 07.07.2020
\end{tabular}

\section{Atıf Bilgisi}

Çakır, U. (2020). Türkiye Türkçesinde Antropometri sistemiyle oluşturulan ölçü birimlerinin anlamsal açıdan bir değerlendirmesi. Ahi Evran Üniversitesi Sosyal Bilimler Enstitüsü Dergisi, 6(2), 404-421.

\section{ÖZ}

İnsanoğlu ilk çağlardan bu yana hayatında yer alan varlık ve nesneleri ölçme eğiliminde olmuştur. Mağara duvarlarına çizilen resimler, çentik sistemi, ay ve güneşin hareketleri gibi ölçme teşebbüsleri daha sonra modern yüzyıllardan itibaren yerini tüm dünyada ortak bir standarta bağlanıp benimsenen ölçü birimlerine bırakmıştır. Buna rağmen insanoğlunun daha ilk yüzyıllardayken bile benimsediği başlıca iki yöntemden biri olan antropometri sistemiyle oluşturduğu ölçü birimleri bugün yerini ilk çağlardaki gibi korumaktadır. Antropometri sistemine göre insanoğlu, ölçümlerinin pek çoğunu bu beş duyu organı ile tecrübe etmekte, hatta bu ölçümleri dile yansıtırken de zaman zaman çeşitli organ adlarını kullanmaktadır. Bu türden organ adlarıyla yapılan ölçümler, bugün gündelik yaşamda en sık başvurulan bir pratik olarak dilde önemli bir yere sahiptir. Çalışmamızda Türkiye Türkçesinde antropometri sistemine göre oluşturulmuş tahminî bir ölçü bildiren ifadeler tespit edilerek anlam açısından sınıflandırılmaya çalışılmıştır. Türkiye Türkçesinde insan bedeni üzerinden oluşturulan ölçü birimlerinde başlıca iki yol izlenmektedir: 1. Doğrudan insan bedeni ve insan bedeninin bölümlerini ifade eden sözcüklerle oluşturulan tahminî ölçü birimleri. 2. Bu organların bazı eylemleri gerçekleştirmek suretiyle alabileceği miktara, bu eylem adlarını vermiştir. Bu iki şekilde oluşturulan ölçü birimleri, anlam ve yapı açısından incelendiğinde Türkçeye muazzam bir katkıda bulunduğu görülmektedir.

Anahtar Kelimeler: Antropometri, ölçü birimi, organ adları, deyimler.

\section{An Evaluation of Terms Semantic From the Anthropometry System Established by Turkish Unit of Measure}

\begin{abstract}
Mankind has been tending to measure the assets and objects in life since the early ages. The paintings drawn on the cave walls, the notch system and the attempts of measurement such as the movements of the moon and the sun were later replaced by the measurement units adopted by a common standard throughout the world. Nevertheless, the measurement units created by the anthropometry system, which is one of the two main methods adopted by mankind even in the first centuries, maintain their place today as in the early ages. According to the anthropometry system, human beings experience many of these measurements with these five sensory organs, and sometimes they use various organ names to reflect these measurements to language. Measurements made with such organ names have an important place in language as the most frequently used practice in daily life today.In our study, the estimated expression indicating a measure created by the system, anthropometry Turkish Turkey were classified in terms of meaning were identified. Turkey created two main ways in which units are monitored through the human body in Turkish: 1. Estimated units of measure formed by words directly expressing the human body and parts of the human body. 2 . It has given the names of these bodies to the amount that these bodies may receive by carrying out certain actions. When the units of measurement formed in these two ways are examined in terms of meaning and structure, it is seen that they have made a tremendous contribution to Turkish.
\end{abstract}

Keywords: Anthropometry, units of measure, organ names, idioms.

\section{Giriş}

Gündelik yaşamın hemen hemen her alanında yer alan ölçü kavramı ve ölçme pratikleri her kültürde o kültürün diline çok sayıda sözcük kazandırmıştır. Bu kazanımlar ya sadece bir ölçü ifade eden müstakil sözcükler ya da mevcut herhangi bir sözcügün ölçü bildiren bir yan anlam kazanmas1 yoluyla oluşmuşlardır. Yani bir dildeki ölçüyle bağıntılı sözcüklerin bir kısmı standart bir ölçüyü bildiren hem derin hem yüzey yapısında ölçü anlamı taşıyan sözcükler iken, büyük bir çoğunluğu da sadece derin yapısında bir ölçü anlamı taşıyan sözcüklerdir. Sözgelimi "bir" sözcüğü derin ve yüzey 
yapıda doğrudan bir miktar ölçüsü bildirirken, "kova" sözcüğü ilk bakışta sedece bir eşya adıdır. "kova", "bir kova su" örneğinde olduğu gibi herhangi bir şeyin miktarını belirlemede bir gündelik yaşam pratiği olarak kullanıldığında ise dildeki bu kullanımı onu derin yapısında bir miktar ölçüsü yapar. Çalışmamıza konu olan organ adlarının ölçü birimi olarak kullanılması da bu örnekte olduğu gibidir. Yani bu ifadeler, yüzey yapıda müstakil olarak bir ölçü bildirmezler. Ancak bazı kullanımlarda derin yapıda ölçü birimi olarak kullanılmaktadırlar.

Bir nicelik veya niteliğin belirlenen birtakım birimler ya da pratikler yardımıyla ne derecede var olduğunu ortaya koyma şeklinde tanımlayabileceğimiz ölçü kavramı, farkında olsak da olmasak da hayatımızın her alanına yayılmış bir kavramdır. Soyut kavramlardan somut varlıklara değin her şey, insanoğlunun temel eğilimlerinden biri olan ölçme davranışından nasibini almaktadır. Bundan iki bin beş yüz y1l önce yaşayan düşünür Protagoras'ın "İnsan, her şeyin ölçüsüdür." sözü bu eğilimi destekler niteliktedir.

\section{Yöntem}

\section{Araştırma Deseni}

Çalışmamızın amacını gündelik yaşamda ne gibi pratiklerle ölçümde bulunuyoruz, bu ölçümler nasıl birer deneyim hâline gelip toplumda yaygınlaşıyor, bunu yaparken seçtiğimiz varlıkların özellikleri nedir ve bütün bunlar dilde yansımasını ne şekilde buluyor sorusunun cevabı oluşturmaktadır. Bu soruyu cevaplamaya çalışırken günlük konuşmada sıkça kullanılan ölçü bildiren ifadeler esas alındı. Bu ifadeler arasından insan bedeni üzerinden yapılan ölçü birimleri seçildi. Seçilen bu ölçü birimlerinin çoğunun varlığı Türkçenin güncel sözlüklerinden birebir bulunarak ispatlanırken günlük konuşma dilinde kullanılan bir kısmının anlamı ise yine sözlükler esas alınarak tarafimizdan yorumlandı.

\section{Evren ve Örneklem}

Türkiye Türkçesinde, insan bedeni üzerinden yapılan ölçü birimleri önemli bir sayısal çoğunluk oluşturmaktadır. Bu nedenle çalışmamızda elde edilen malzeme, ölçünlü Türkiye Türkçesinin söz varlığını barındıran Büyük Türkçe Sözlük taranarak elde edildi. Bu sözlük, bilimsellik ve güvenilirlik açısından Türk Dil Kurumu yayınları arasından seçildi.

\section{Verilerin Analizi}

Çalışmamızda elde edilen veriler iki ana gruba ayrıldı: 1. Doğrudan organ adlarıyla oluşturulan ölçü birimleri. 2. Organların eylemlerini esas alan ölçü birimleri. Çalışmamızda elde edilen veriler, on bir alt başlık - ölçü türü- olarak belirlendi: Ağırlık, boyut, hız, kalınlık-incelik, mesafe, miktar, para, renk, uzunluk, yön, zaman.

Verilerin analizinde iki ana gruba ayrılan çalışmamızda bu alt ölçü türlerinin bazılarının örneklerine birinci grupta rastlanırken (doğrudan organ adları ile oluşanlar), ikinci grupta (organların eylemlerini esas alarak oluşanlar) aynı ölçü türü için bir kullanım bulunamadı. Bu yüzden örneği olmayan ölçü türleri için bu iki ana grupta başlıklar açılamadı. Doğrudan organ adları ile oluşan ölçü birimleri için "boyut, hız, kalınlık-incelik, mesafe, miktar, para, renk, uzunluk, yön, zaman" bildiren ölçü türleri başlıkları açıldı. Organların eylemleri esas alınarak oluşturulan ölçü birimleri için ise "hız, mesafe, miktar, zaman, uzunluk" bildiren ölçü türleri başlıkları açıldı.

Türkiye Türkçesinde doğrudan organ adlarıyla oluşturulan ölçü birimlerinin deyimleşmiş olanlarının da büyük bir çoğunlukta olması nedeniyle çalışmamızda iki ana grubun bulgularının değerlendirilmesinin sonuna deyimleşmiş ölçü bildiren ifadeler için de ayrı bir başlık açıldı. Bu başlık da diğer iki ana başlıkta uygulanan yöntemle incelendi. Deyimleşmiş ölçü birimleri, "ağırlık, boyut, 
hız, kalınlık-incelik, mesafe, miktar, para, renk, uzunluk, zaman" bildiren ölçü türleri ile alt başlıklara ayrılıp örneklendirildi.

Bu ölçü türlerinin malzemeleri sıralanırken standart sözlük yöntemi kullanıldı. Her ölçü türü başlı̆̆ının altına eldeki malzemeden uygun olanlar, maddebaşları şeklinde alfabetik olarak sıralandı. Her madde başının anlamı verildi. Madde başı birden fazla anlama sahipse bu farklı anlamlar, rakamlarla ayrı ayrı verildi. Her maddebaşına uygun örnekler italik harflerle sıralandı.

\section{Bulgular}

Ölçü birimlerini her toplum için gerekli olan standart ihtiyaçlar (yön belirleme, zaman belirleme, mesafe belirleme vb.) belirlemişse de her toplum kendi ölçü birimlerini yaşadığı coğrafya, sahip olduğu nesne ve varlıklar üzerinde zekâsını kullanarak farklı farklı belirlemiştir. Daha kısa bir ifadeyle aynı ihtiyaçlar, farklı araçlar ve adlandırmalar aracılı̆̆ıyla bir ölçüye bağlanılarak giderilmiştir. Söz gelimi hesaplarını çubuk atış veya ok atış mesafesine, sesin yayılma mesafesine; çıplak gözle yerden veya deve sırtından görüş mesafesine; gün doğumundan batımına veya sabah erken saatten, gün ortasından, sabahın geç saatinden gün batımına yürüme mesafesine; yüksüz bir insanın yürüme mesafesine, kendi yüklü, eşeği yüklü veya yanında öküzü olan bir insanın yürüme mesafesine; kolay veya zorlu araziyi yürüyerek aşma mesafesine göre yapmışlardır (Robinson, 2007, ss, 10-11).

İnsanoğlunun geçmiş zamanlarda ölçme konusunda başvurduğu başlıca iki yöntem vardır: Birincisi kendi bedeni, ikincisi çevresindeki varlıklar üzerinden doğrudan veya benzetme yapmak suretiyle dolaylı bir şekilde ölçü sözleri oluşturmasıdır. Bu türden benzetmeler, ölçüm aletlerinin ve ölçü birimlerinin çok geliştirilmiş olduğu hatta standartlara indirgendiği günümüzde bile gündelik hayatta hâlen kullanılmakta, başlıca ölçme pratiklerinin başında gelmektedir.

İnsanoğlu ölçme konusunda, teknolojinin gelişmediği eski çağlarda antropometri sistemini esas almıştır. Evrensel bir yaklaşım olarak değerlendirebileceğimiz bu ölçülendirmede, insanın vücudunda ve çevresinde gözlemlediği doğal ve yerel birtakım mukayese ve ölçek araçlarına başvurduğu ve onları kullandığı görülür (Özyetgin, 2005, s. 195). Antropometri kimi kaynaklarda yanlış bir kullanımla bilim olarak adlandırılsa da pek çok bilim dalına yardımcı olan bir tekniktir. Antropometri tekniği sayesinde insan vücudunda belirlenmiş sabit noktalar yardımıyla 200'ün üzerinde antropometrik ölçü alınabilmektedir (Önal, 2016, s.100).

İnsanın beş duyu organı en çok kullanılan ve en esaslı ölçme araçlarıdır. İnsanoğlu ölçümlerinin pek çoğunu beş duyu organı ile tecrübe etmekte, hatta bu ölçümleri dile yansitırken de zaman zaman bedeni üzerinden yaptığı benzetmeleri kullanmaktadır. $\mathrm{Bu}$ şekilde insan bedeni üzerinden yapılan ölçümler, bugün bile gündelik yaşamda en sık başvurulan bir pratik olarak dilde önemli bir yere sahiptir.

İnsanın kendi bedeni üzerinden benzetme yapmak suretiyle oluşturduğu bu ölçü birimleri, elbette çok net, standart bir ölçüyü bildirmezler. Ancak genel geçer, tahminî bir ölçü birimi oluşturmak için de birebirdirler. Çünkü insan bedeni fizyolojik açıdan kişiden kişiye farklılıklar gösterebilir. Söz gelimi "bir avuç findık" ifadesinde avuç büyüklüğü kişiden kişiye farklılık gösterir. Buna bağlı olarak da büyük bir avucun alacağ 1 findık miktarı ile küçük bir avucun alacağg findık miktarı arasında fark vardır. Bu tür ölçü ifadeleri bu yönüyle standart bir ölçü bildirmezler. Ancak yine de "bir avuç", o dili konuşan herkesin zihninde aşağı yukarı tahmin edilebilecek sınırları belli olan bir miktarı ifade eder. Bu yönüyle insan bedeni üzerinden oluşturulan ölçü birimleri, tahminî bir ölçüyü ifade ederler.

Diğer kültürlerde de benzer bir tutum söz konusudur. İnsan bedeni ile tohum ve tahıllar, dünyanın dört bir yanında tipik geleneksel uzunluk birimleri olarak kullanılırlar. Henüz metrik sisteme geçmemiş ülkelerden biri olan Myanmar'daki (Burma), kimisi hâlen kullanımda olan geleneksel uzunluk birimleri olan 10 sançi (bir saç telinin eni) $=1 \mathrm{hnan}$ (bir susam tanesi), $6 \mathrm{hnan}=1$ muyav (bir 
pirinç tanesi), 4 muyaw = 1 let-thit $($ bir parmak eni), 6 let-thit $=1$ maik (parmaklar açık halde bir avuç eni), 12 let-thit = 1 twa (bir karış) şeklindeki kullanımlar da bu durumu açıkça göstermektedir (Robinson, 2007, s. 51).

Türkiye Türkçesinde insan bedeni üzerinden oluşturulan ölçü birimlerinde başlıca iki yol izlenmektedir:

1. Doğrudan insan bedeni ve insan bedeninin bölümlerini ifade eden sözcüklerle oluşturulan tahminî ölçü birimleri:

ăgız, alın, avuç, aya, bacak, baş, beniz, bilek, boğaz, boy, bögür, burun, çene, deri, dirsek, diş, diz, dudak, eğin, el, ense, geniz, göbek, göğ̈̈s, göz, kafa, karın, kelle, kemik, kul, kol, kucak, kulak, kulak memesi, meme, omuz, parmak, sirt, surat, ten, tırnak, topuk, tüy, yanak

2. Bu organların bazı eylemleri gerçekleştirmek suretiyle alabileceği miktara, bu eylem adlarını vermiştir:

adım, atım, çağırım, çiynem, çimdik, çitmik, dizim, düzüm, doğram, dolam, erim, giyim, görüm, ışırım, içim, koşum, kulaç, sıkım, sıvam, sokum, suvarım, tadım, tıkım, tutam, yalamtık, yudum, yoğurum

Bu iki şekilde oluşturulan ölçü birimleri, anlam ve yapı açısından incelendiğinde Türkçeye muazzam bir katkıda bulunduğu görülmektedir.

\section{Doğrudan Organ Adları Kullanılarak Oluşturulan Ölçü Birimleri}

\section{Boyut Ölçüsü Bildirenler}

- avuç: Bir ele sığabilecek boyutta olan. $\rightarrow$ avuç kayası (Küçük taş.)

- aya: Nesne adları yapan ad tamlamalarında söz konusu nesnenin avuç büyüklügünde olduğunu belirtir. $\rightarrow$ aya taşı (Avuç içine sığabilecek boyutta olan taş, sapan taşı.)

- boy boy: Çeşitli büyüklük ve nitelikte. $\rightarrow$ boy boy çocuklar, boy boy dağlar, boy boy koltuklar vb.

- cep boy: Cebe sığacak büyüklükte olan. $\rightarrow$ cep boy kitap, cep boy şemsiye vb.

- el: Nesne adları yapan ad tamlamalarında söz konusu nesnenin el büyüklüğünde, taşınabilecek veya elde kullanılabilecek boyutta olduğunu belirtir. $\rightarrow$ el bombast, el çantast, el feneri, el havlusu, el kayasl, el keseri, el kılavuzu, el lambası, el sözlüğü, el tarağı vb.

- göbekli: Karnı yağlanıp şişmanlamış, göbeği büyük. $\rightarrow$ göbekli adam, göbekli kadın vb.

- göğüslü: 1. Göğsü geniş olan. $\rightarrow$ göğüslü kişi vb. 2. Büyük memeli. $\rightarrow$ göğüslü kadın, göğ̈̈slü klz vb.

- kafam kadar: Çok büyük. $\rightarrow$ kafam kadar ekmek, kafam kadar elma vb.

- kalçalı: Kalçası geniş olan. $\rightarrow$ kalçalı kişi, kalçalı kadın vb.

- karınlı: Karnı büyük ve çıkıntılı olan. $\rightarrow$ karınlı adam, karınlı kadın vb.

- kuşbaşı: Küçük bir kuşun başı büyüklüğünde doğranmış (et vb.). $\rightarrow$ kuşbaşı et, kuşbaşı kavurma vb.

- parmak kadar: Çok küçük, ufak. $\rightarrow$ Parmak kadar çocuktan ne istiyorsun?

- tırnak kadar: Çok küçük. $\rightarrow$ tırnak kadar parça, tırnak kadar küpe vb.

- yanaklı: Yan yüzeyinde belirgin şişkinlik olan (nesne). $\rightarrow$ yanaklı lastik vb.

\section{Hız Ölçüsü Bildirenler}

- ayak: Yürüyüşün ağırlık veya çabukluk derecesi. $\rightarrow$ ayağı ă̆ır, ayağı çabuk, ayağı çevik, ayă̆ına çabuk $\mathrm{vb}$.

- baş döndürücü: Çabuklukta olağanüstü, aşırı. $\rightarrow$ baş döndürücü değişim, baş döndürücü hız, baş döndürücü sürat vb.

- yel ayaklı: Yüğrük, hızlı koşan. 


\section{Kalınlık-İncelik Ölçüsü Bildirenler}

- kıl: İnce, çok ince. $\rightarrow$ kll burun (Denizin içine uzanmış ince kara parçası.), kll kurt (Soğuktan, nemden canlıların ciğerlerinde, nefes borularında olan ince uzun bir kurt.), kılkuyruk (Ördekgillerden, uzunluğu 55-65 santimetre, kuyruğu sivri, tüyleri ak yeşil karışık, gagası, ayakları mavi bir tür kuş.), kll otu (Dağlık çayırlarda yetişen ince ve sert yapraklı bir bitki.), kll testere (Çok ince bir tür testere.)

- kıl gibi: Çok ince. $\rightarrow$ kl gibi kalem, kal gibi tel vb.

- kılcal: Kıl gibi olan, çok ince. $\rightarrow$ kllcal boru, kılcal damar, kılcal kök vb.

- kol gibi: Çok kalın. $\rightarrow$ kol gibi hamur vb.

- yılan ayağı: Görülmeyecek kadar ince.

\section{Mesafe Ölçüsü Bildirenler}

- adımbaşı: Birbirine yakın yerlerde. $\rightarrow$ Sokaklarında adımbaşı kahve dükkânları vardı.

- baş: Bir şeyin yakını veya çevresi. $\rightarrow$ çeşme başı, havuz başı, yanı başı vb.

- baştan aşağı: Bir uçtan öbür uca kadar. $\rightarrow$ Beni baştan aşağı süzdü.

- dirsek dirseğe: Çok sıkışık bir durumda ve yan yana. $\rightarrow$ Askerler dirsek dirseğe kenetlendiler.

- diz dize: Dizleri birbirine değecek biçimde birbirine yakın olarak. $\rightarrow$ Yerlerine geçip diz dize oturdular.

- dudak payı: Bardak, fincan vb. kapları, ağzına kadar doldurmayıp dudağın yanaşabileceği kadar boş bırakılan mesafe.

- göz göze: Gözleri birbirlerine bakacak kadar yakın bir şekilde. $\rightarrow$ Saatlerce göz göze oturdular.

- koyun koyuna: Birbirlerinin koyunlarında, birbirlerine çok yakın olarak. $\rightarrow$ Ana kız koyun koyuna uyudular.

- omuz omuza: Çok sıkışık bir durumda, yan yana. $\rightarrow$ Cephede omuz omuza savaştılar.

- sırt sırta: Arka arkaya, sırtları birbirine değecek bir biçimde. $\rightarrow$ Soğuk durakta sirt sırta otobüs bekledik.

- yanak yanağa: Yanakları birbirine değecek kadar yakın olarak. $\rightarrow$ Çocuk, kediyle yanak yanağa saatlerce oturdu.

\section{Miktar Ölçüsü Bildirenler}

- adımbaşı: Sık sık. $\rightarrow$ Yürürken adımbaşı bir satıcıya rastllyorduk.

- ağız: Kez, kere, defa. $\rightarrow$ ilk ă̆ızda (Önce, öncelikle, ilk iş olarak, her şeyden önce.)

- ağız ağıza: Ağzına kadar, tamamen. $\rightarrow$ Salon ağız ağıza insanla dolmuştu.

- avuç: Elin alacağı miktarda olan. $\rightarrow$ bir avuç buğday, bir avuç çekirdek, bir avuç su, iki avuç findik $v$.

- avuç avuç: 1. Bol bol, pek çok. $\rightarrow$ avuç avuç altın, avuç avuç buğday, avuç avuç çekirdek, avuç avuç kum, avuç avuç para vb. 2. Avuçlar dolu olarak, pek çok avuç miktarıyla. $\rightarrow$ Suları avuç avuç içti.

- avuç unu: Değirmencinin öğüttüğü undan aldığı hak.

- ayakaltt: Gelip geçenlerin çok olduğu yer.

- baş: 1. Kasaplık hayvanlarda ve bazı yiyeceklerde adet. $\rightarrow$ üç baş koyun, iki baş soğan vb. 2. İnsan sayımında tane. $\rightarrow$ adam başı (mkt. zf. Her bir bireye, her birine, kişi başına.), kişi başı (Adam başina.) vb.

- diş: Sarımsak dilimi ve karanfil vb. dişe benzetilen şeylerde tane. $\rightarrow$ bir diş karanfil, iki diş sarımsak vb.

- diş diş: Birçok diş miktarında olan. $\rightarrow$ diş diş karanfil, diş diş sarımsak vb.

- parmak: Koyu sıvılara daldırılıp çıkarıldığında parmağa bulaşan miktarda olan. $\rightarrow$ bir parmak bal, bir parmak çikolata, bir parmak dondurma, bir parmak pekmez, bir parmak reçel, bir parmak sütlaç, bir parmak tahin vb. 
- parmak parmak: 1. Birçok parmak miktarında olan. $\rightarrow$ parmak parmak bal, parmak parmak pekmez, parmak parmak reçel vb. 2. Birkaç parmak miktarınca. $\rightarrow$ Kavanozun dibini parmak parmak siyırdi.

- tırnak kadar: Çok az. $\rightarrow$ tırnak kadar baharat, tırnak kadar tuz vb.

\section{Para Ölçüsü Bildirenler}

- baş: Para değiştirirken verilen veya alınan üstelik, sarrafiye.

- başlık: Bazı bölgelerde, evlenirken, damadın kaynatasına ödemesi görenek olan para.

\section{Renk Ölçüsü Bildirenler}

- camgöbeği: 1 . Yeşile çalan mavi renk. 2. Bu renkte olan. $\rightarrow$ camgöbeği elbise, camgöbeği kumaş, camgöbeği renk vb.

- devetüyü: 1 . Deve tüyü rengi, açık kahverengi. 2. Bu renkte olan. $\rightarrow$ devetüyü kazak, devetüyü manto, devetüyü mobilya $\mathrm{vb}$.

- fildişi: 1. Fil dişinin donuk beyaz rengi. 2. Bu renkte olan. $\rightarrow$ fildişi etek, fildişi gömlek, fildişi kapı, fildişi kolye, fildişi taş $\mathrm{vb}$.

- göz perdesi: Göze inen boz leke.

- güvercingöğsü: 1. Yeşil ile mavi arasında böcekkabuğuna benzer dalgalı ve değişken renk. 2. Bu renkte olan. $\rightarrow$ güvercingöğsü bitki, güvercingöğsü elbise, güvercingöğsü ot vb.

- kazayağı: 1. Açık turuncu renk. 2. Bu renkte olan. $\rightarrow$ kazayağ elbise, kazayağı kumaş, kazayă̆

- kemik rengi: 1. Beyaz ile krem rengi arasında olan renk. 2. Bu renkte olan. $\rightarrow$ kemik rengi ayakkabı, kemik rengi kumaş vb.

- ten rengi: 1 . İnsan teninin rengi. 2. Bu renkte olan. $\rightarrow$ ten rengi çorap, ten rengi kazak vb.

- tavşankanı: 1. Parlak ve koyu kırmızı renk. 2. Bu renkte olan. $\rightarrow$ tavşankanı çay

- turnagözü: 1. Berrak ve parlak sarı. 2. Bu renkte olan. $\rightarrow$ turnagözü çarşaf, turnagözü gömlek, turnagözü kumaş, turnagözü saç vb.

- yavruağzı: 1. Kavuniçi ile pembe arası bir renk. 2. Bu renkte olan. $\rightarrow$ yavruağzı çanta, yavruăgzı kazak, yavruağzl salon vb.

\section{Uzunluk Ölçüsü Bildirenler}

- adım: 1. Bir ayak atışıyla alınan, uzunluğu yaklaşık $75 \mathrm{~cm}$ 'lik yol. 2. Sporda ayakta, esas duruşta, bir ayağın türlü yönlerde iki ayak boyu kadar yer değiştirmesi.

- ayak: Yarım arşın veya 30,5 cm uzunluğundaki ölçü birimi, kadem.

- ayak basımı: Yere basan bir ayağın boyunca olan yer.

- bacaklı: Bacakları uzun olan, uzun boylu.

- bacaksiz: Bacakları kisa olan, kısa boylu, bodur.

- bastıbacak: Bacakları kısa ve çarpık (kimse). $\rightarrow$ bastıbacak adam, bastıbacak kadın, bastıbacak kzz, bastıbacak oğlan vb.

- bilek boy: Giyilen şeyler için uzunluğu ayak bileğine kadar olan. $\rightarrow$ bilek boy çorap, bilek boy etek, bilek boy pantolon $\mathrm{vb}$.

- boy : 1. Bir şeyin tabanı ile en yüksek noktası arasındaki mesafe. $\rightarrow$ boy abdesti, boy aynası 2. Bir yüzeyde, en sayılan iki kenar arasındaki mesafe; en, genişlik karşıtı. 3. Uzunluk. $\rightarrow$ adam boyu, dalga boyu, diz boyu, fidan boylu, insan boyu, minare boyu, palamar boyu, yazı boyu vb. 4. Kumaş için ölçü. $\rightarrow$ dirsek boyu, etek boyu, kol boyu, omuz boyu vb.

- boylu: Boyu benzerlerinden uzun olan. $\rightarrow$ Sahneye esmer, zayıf ve boylu bir delikanlı çıktı.

- boylu boyunca: Boyu uzanabildiği kadar, boyu uzunluğunca.

- boylu poslu: bk. boylu boslu. $\rightarrow$ boylu poslu adam, boylu poslu delikanl, boylu poslu kadin, boylu poslu klz, boylu poslu oğlan vb.

- boysuz: Boyu kısa olan. $\rightarrow$ boysuz adam, boysuz çocuk, boysuz kadın, boysuz kişi vb. 
- diz boyu: Dizlere kadar olan uzunlukta, yükseklikte. $\rightarrow$ diz boyu çamur, diz boyu kar vb.

- kol kadar: Çok uzun. $\rightarrow$ kolum kadar havuç, kol kadar patlican vb.

- parmak: 1. Arşının yirmi dörtte biri. 2. Eni el parmağı kadar olan. $\rightarrow$ beş parmak eninde, bir parmak aralık, iki parmak uzunluk vb. 3. Çok kısa boylu kimse. $\rightarrow$ bir parmak (Kısa boylu.), parmak adam, parmak çocuk, parmak kadın, parmak kız vb.

\section{Yön Ölçüsü Bildirenler}

Organ adlarından oluşturulan yön ölçüsü birimleri, çoğunlukla gerçek anlamlarından uzaklaşarak edinilmiş yan anlamlardır. Ancak bu yan anlamlar, organın şekli esas alınarak benzetme yoluyla oluşturulmuştur.

- ağız: 1. Kapların veya içi boş şeylerin açık tarafi. $\rightarrow$ bidonun ağzl, çanağın ağzl, çömleğin ăgzl, kavanozun ăgzl, kovanin ağzl, yanardăg ăgzl vb. 2. Uç, kenar. $\rightarrow$ dört yol ăgzl, kapı ăgzl, kol ă̆zl, mide ăgzl, uçurum ăgzl, yol ăgzl vb.

- alın: 1. Bazı şeylerin önü, ön yüzü. $\rightarrow$ balkon alnı vb. 2. Karşı. $\rightarrow$ güneşin alnı vb.

- ayakı başı: İki kişinin bir yatakta birinin ayağı diğerinin başına gelecek şekilde yatmaları. $\rightarrow$ Çocuklar dün gece ayaklı başll yattılar.

- baş: 1. Deniz teknelerinde ön taraf. 2. Bir şeyin uçlarından biri. $\rightarrow$ merdivenin başı, tespih başl vb.

- boğaz: Bazı nesnelerde ağza yakın dar bölüm. $\rightarrow$ botun boğazı, kazağın boğazı vb.

- boy : Yol, ırmak, deniz kiyıs1. $\rightarrow$ deniz boyu, dere boyu, ırmak boyu, kordon boyu, nehir boyu, sahil boyu, sinir boyu, yol boyu vb.

- boyun: Bazı nesnelerde dar olan üst kısım. $\rightarrow$ gügüümün boynu, şişenin boynu, testinin boynu vb.

- böğür:Yan taraf. $\rightarrow$ binanın böğrü, masanın böğrü vb.

- burun: Bazı şeylerin ön ve sivri bölümü. $\rightarrow$ ayakkabının burnu, geminin burnu vb.

- burun buruna: Birbirine çok yakın ve yüz yüze bir biçimde. $\rightarrow$ Ikki arkadaş köşseyi dönünce burun buruna geldiler.

- çalkoyun: Sirtüstü.

- çene: Bazı nesnelerin uç tarafı. $\rightarrow$ çene kısmı, çene tarafi vb.

- dirsek: Köşe. $\rightarrow$ sobanın dirseği vb.

- eğin: Arka, sirt. $\rightarrow$ dananın ĕgni, gömleğin ĕgni vb.

- ense: Bazı nesnelerin arkası. $\rightarrow$ dağın ensesi vb.

- göbek: 1. Şehir, ülke vb. nin orta kısm1. $\rightarrow$ kasabanın göbeği, köyün göbeği, şehrin göbeği vb.

2. Bazı sebze ve meyvelerin orta kısmı. $\rightarrow$ marulun göbeği, soğanın göbeği vb. 3. Bahçe, halı, tavan, tepsi vb. süslü şeylerin ortalarındaki biçim. $\rightarrow$ halının göbeği, tepsinin göbeği $\mathrm{vb}$.

- göz: Uç, taraf. $\rightarrow$ pinarın gözüu, suyun gözü vb.

- karın: Bazı şeylerin şiş ve içi boş kısmı. $\rightarrow$ geminin karnı, şişenin karnı vb.

- kol: Taraf, yan, cihet. $\rightarrow$ Düşman ü̧̧ koldan saldırdl.

- sırt: Bir şeyin üstü, üst bölümü. $\rightarrow$ dağ sirtı, dalga sirtı vb.

- taban: 1. Bir şeyin en alt bölümü. $\rightarrow$ ayak tabanı, kutunun tabanı, odanın tabanı vb. 2. Üstü kapalı bir yerin gezinilen, ayakla basılan yüzü, tavan karşı1tı. $\rightarrow$ taban halısı vb.

- yüzükoyun: Yüzüstü. $\rightarrow$ Yatağa yüzükoyun yattl.

- yüz yüze: Karşı karşıya, yüzler birbirine bakarak. $\rightarrow$ Odaya geçip yüz yüze görüş̧ı̈ler.

\section{Zaman Ölçüsü Bildirenler}

- el : 1. İskambil oyunlarında kağıt atma sırası. $\rightarrow$ bir el (İskambil, tavla vb. oyunlarda bir tur oyun.) 2. Ateşli silahlarda atım miktarı. $\rightarrow$ bir el (Ateşli silah için bir kez atım.), iki el (Ateşli silah için iki kez atım.) vb.

- kucakta: Henüz yürüyemeyen küçük çocuk.

- memede: Henüz annesini emerek beslenme döneminde olan bebek. 
- peynir dişi: Çok yaşlılarda çıkan kuzu dişi.

- süt dişi: Bebeğin beş veya altı aylıkken çıkarmaya başladığı, yedi yaşlarında kendiliğinden dökülen diş.

\section{Organların Bazı Eylemleri Gerçekleştirdiğinde Oluşan Ölçü Birimleri}

\section{Hız Ölçüsü Bildirenler}

- adım adım: Ağır ağır, yavaş yavaş.

- kadem kadem: bk. "adım adım"

- yudum yudum: Yavaş yavaş. $\rightarrow$ Çayı yudum yudum içti.

\section{Kalınlık-İncelik Ölçüsü Bildirenler}

- kıyım kıyım: 1. İnce bir şekilde olan. $\rightarrow$ klyım kıyım biber, kıyım kıyım domates, klyım kıyım patates, klyım kıyım soğan vb. 2. İnce ince. $\rightarrow$ Etleri kıyım kıyım doğradılar.

\section{Mesafe Ölçüsü Bildirenler}

- adım: Adım, bir adım mesafesinde. $\rightarrow$ iki adım, beş adım vb.

- atım yeri: Ok ya da kurşun menzili, okun ya da kurşunun erişebileceği yer.

- bir koşumluk: Koşarak gidince hemen varılacak kadar yakın (yer). $\rightarrow$ bir koşumluk yer vb.

-... atımı yer: Atılan bir şeyin çıkış noktasıyla ulaştığı nokta arasındaki mesafe. $\rightarrow$ bir kurşun atımı yer, bir ok atımı mesafe vb.

- erim: Bir şeyin erebileceği mesafe, menzil. $\rightarrow$ el erimi, göz erimi, kulak erimi, kurşun erimi, ok erimi, taş erimi vb.

- iki adımlık: Çok yakın (yer). $\rightarrow$ iki adımlık mesafe, iki adımlık yer vb.

- kadem: Adım, bir adım mesafesinde. $\rightarrow$ bir kadem, iki kadem vb.

- kulaç: Gerilerek açılmış iki kolun parmak uçları arasındaki mesafe. $\rightarrow$ bir kulaç, iki kulaç vb.

- kulaç kulaç: 1. Kulaçlarca, birden çok kulaç uzunluğunda. $\rightarrow$ kulaç kulaç aralık, kulaç kulaç ip, kulaç kulaç kumaş, kulaç kulaç mesafe vb. 2. Kulaçlar hâlinde. $\rightarrow$ Kulaç kulaç yüzerek geldi. - seğirdim: 1. Bir koşuşta alınan yer, mesafe. 2. Bir atılışta gidilecek yer. $\rightarrow$ bir seğirdimlik yer vb.

\section{Miktar Ölçüsü Bildirenler}

- çimdik: Baş parmakla işaret parmağının ucu arasına alınan miktarda olan. $\rightarrow$ bir çimdik tuz, iki çimdik karabiber vb.

- çitmik: Çimdik.

- çiynem: Bir kez çiğnenecek miktarda olan. $\rightarrow$ bir çiynem ekmek, bir çiynem lokma, bir çiynem lokum vb.

- dizin dizin: bk. "dizim dizim"

- dizim dizim: 1 . Peş peşe dizilmiş. $\rightarrow$ dizim dizim asker, dizim dizim boncuk vb. 2. Dizilmiş olarak, dizi dizi. $\rightarrow$ Öğrenciler bahçede dizim dizim oldular.

- doğram: Doğrama sonucu ortaya çıkan parça. $\rightarrow$ bir doğram et, iki doğram ekmek vb.

- dolam: Bir kez dolanacak miktarda olan. $\rightarrow$ bir dolam ip, iki dolam hortum vb.

• düzüm düzüm: bk. "dizin dizin", "dizim dizim"

- elçim: 1. Bir defada ele alınabilecek kadar az olan nesne. $\rightarrow$ bir elçim ot, bir elçim şeker, bir elçim tuz vb. 2. Tutam, bir demet, bir parça. $\rightarrow$ bir elçim maydonoz, bir elçim tuz vb.

- giyim: Giyilecek olan şeylerde tane, adet. $\rightarrow$ bir giyim etek, iki giyim gömlek vb.

- kucak: Bir kucağın alabileceği miktarda olan. $\rightarrow$ bir kucak çiçek, bir kucak kumaş vb.

- kucak kucak: 1. Bol bol. $\rightarrow$ kucak kucak elma, kucak kucak çiçek, kucak kucak toprak vb. 2. Kucaklanabilecek miktarda olan. $\rightarrow$ kucak kucak çiçek, kucak kucak elma, kucak kucak gül vb. 
- sarım: Bir şeyi bir kez saracak miktar. $\rightarrow$ bir sarımlı tütün, bir sarımlık yaprak vb.

- sıkım: 1. Kapalı elin alabildiği miktar. $\rightarrow$ bir sıkım çekirdek, bir sıkım kum vb. 2. Bir defada sıkılan miktar. $\rightarrow$ bir sıkım hamur, bir sıkım köfte vb. 3. Ateşli silahlarda bir atış için yeterli olan miktar. $\rightarrow$ bir sıkım atış vb.

- sıkın: Avuç içinde sıkılan miktar. $\rightarrow$ bir sıkın hamur, bir sıkın köfte vb.

- silme: Bir tutuşta biçilen ekin.

- sokum: Lokma, ağza bir defada alınan yiyecek miktarı. $\rightarrow$ bir sokum et, bir sokum pilav, bir sokum yemek $\mathrm{vb}$.

- sokum sokum: 1. Birçok sokum miktarında. $\rightarrow$ sokum sokum ekmek, sokum sokum lokma, sokum sokum yemek vb. 2. Lokma lokma. $\rightarrow$ Pilavdan sokum sokum yedik.

- suvarım: mkt. is. Bir suvarmada veya sulamada verilen su miktarı. $\rightarrow$ bir suvarım su, iki suvarim su vb.

- tadak madak: Miktarı az olan yiyecek, tadımlık. $\rightarrow$ tadam madak et, tadak madak peynir, tadak madak yemek, tadak madak yumurta vb.

- tadım: Tadına bakmak için bir şeyden ağza alınan miktar. $\rightarrow$ bir tadım yemek vb.

- tadımlık: Tadını alacak kadar miktarda olan. $\rightarrow$ Pastadan tadımlık yedik.

- tıkım: Ağzın alabileceği boyutta lokma. $\rightarrow$ bir tıkım lokma, iki tıkım ekmek vb.

- tutam: Avuç içi veya parmak uçlarıyla tutulabilen miktarda olan. $\rightarrow$ bir tutam maydonoz, iki tutam ot, bir tutam para, bir tutam saç vb.

- tutam tutam: 1. Tutulacak kadar birçoğu bir arada olan. $\rightarrow$ tutam tutam maydonoz, tutam tutam ot, tutam tutam para, tutam tutam saç vb. 2. Birçok tutam miktarıyla. $\rightarrow$ Saçları tutam tutam dökülüyor.

- yalamtık: Yalayacak kadar, pek az, bir parça (yemek). $\rightarrow$ yalamtık bal, yalamtık pekmez, yalamtık yoğurt vb.

- yoğurum: Yoğrulacak kadar olan. $\rightarrow$ bir yoğurum hamur, bir yoğurum harç vb.

- yudum: Bir içişte yutulacak miktar. $\rightarrow$ bir yudum su, iki yudum şarap vb.

- yudum yudum: Azar azar. $\rightarrow$ Suyu yudum yudum içti.

\section{Uzunluk Ölçüsü Bildirenler}

- uzanımlık: Uzanıldığında erişilecek uzunlukta olan. $\rightarrow$ bir uzanımlık raf vb.

\section{Zaman Ölçüsü Bildirenler}

- çağırımlık: Şark1, türkü için bir kez söyleyecek kadar süre, zaman. $\rightarrow$ bir türkü çağırımlık süre vb.

- görümlük: Bir kez görülecek kadar zaman, süre. $\rightarrow$ bir görümlük süre vb.

- içimlik: Bir şey içilecek kadar süre, zaman. $\rightarrow$ bir kahve içimlik süre, bir sigara içimlik süre vb.

\section{Organ Adları Kullanılarak Oluşturulan Deyimleşmiş Ölçü Birimleri}

\section{Ağırlık Ölçüsü Bildirenler}

- eti kemiği: Asıl ağırlığı.

- tüy gibi: Hafif.

\section{Boyut Ölçüsü Bildirenler}

- avuç içi kadar: Çok küçük, dar, genişliği az olan (yer, mekân). $\rightarrow$ avuç içi kadar yer, avuç içi kadar oda vb.

- avurtları çökmek (veya avurtları birbirine geçmek): Çok zayıfladığı yüzünden belli olmak.

- avurdu avurduna geçmek: Çok zayıflamak. 
- bacak kadar: Ufacık. $\rightarrow$ bacak kadar çocuk, bacak kadar klz vb.

- baştan aşağı: Bütün vücudu, her yanı. bk "başstan ayağı"

- baştan ayağı: Bütün vücudu, her yanı.

- baştan başa: Tamamıyla, bütünüyle.

- bir boydan bir boya: Bir yerin bir ucundan öbür ucuna kadar, baştan başa.

- bir deri bir kemik (kalmak): Çok zayıflamak.

- bir sıkımlık (pençelik) canı olmak: Hemen mahvolacak kadar zayıf olmak.

- bir torba kemik: Çok zayıf.

- boydan boya: Bir uçtan öbür uca.

- boynu armut sapına dönmek: Çok zayıflayıp boynu incelmek.

- burnunu sıksan canı çıkacak: Çok zayıf ve güçsüz kimseler için kullanılan bir söz.

- derisi kemiklerine yapışmak: Çok zayıflamak.

- el kadar: Küçük, küçücük.

- enine boyuna: İriyarı (adam).

- ense kulak yerinde: İri yarı (erkek).

- eti budu yerinde: Şişmanca, tombul.

- etli butlu: Bedeni geniş, kilolu, şişman.

- etten tenden düşmek: Çok zayıflamak.

- göbek bağlamak (salıvermek): Şişmanlayarak karnı büyümek, göbeklenmek.

- gövde bağlamak: Şişmanlamak, semirmek.

- iskelete dönmek: Çok zayıflamak.

- iskeleti çıkmak: Çok zayıflamak.

- kaburgaları çıkmak (veya sayılmak): Çok zayıf olmak.

- karın kasık salmak: Çok şişmanlamak, göbek bağlamak.

- karnı karnına geçmiş: Zayıflıktan karın yuvarlağı içine çökmüş.

- kelle kulak yerinde (olmak): İri yapılı olan.

- kemer patlıcan gibi burun: İri ve toparlak burun.

- kemikleri sayılmak: Çok zayıflamak.

- surat bağlamak: Şişmanlayıp yüzü irileşmek.

- tepeden tırnağa (kadar): Bütün vücudu, her yanı. bk. "baştan aşağ

\section{Hız Ölçüsü Bildirenler}

- adımlarını açmak: Yürürken hızlanmak.

- adımlarını seyrekleştirmek: Hızlı yürürken adımlarını yavaşlatmak.

- adımlarını sıklaştırmak: Daha küçük ve çabuk adımlar atarak hızlı yürümek, ivmek, acele etmek.

- at boynuna düşmek: Atı boynu üzerine eğilip hızlı sürmek.

- ayağa durmak: Derece derece, adım adım, yavaş yavaş.

- ayağına çabuk: Bir yere alışılandan daha kısa sürede gidip gelen.

- ayak götürmek: Çabucak çekilip gitmek.

- ayak sürümek: Verilen bir işi ağırdan almak, yavaş yapmak.

- baş döndürücü: Çok hızlı, izlenmesi olanaksız denebilecek ve insanı şaşırtacak bir hızla.

- bir çırpıda (çıkarmak): Ele alır almaz, bir davranışta yapıp bitirmek.

- bir çırpıda: Hemen.

- bir koşu: Çabucak.

- bir solukta: Çarçabuk, hemen.

- el çabukluğu ile: Hilesini kimseye sezdirmeyecek bir çabuklukla.

- elden gel: Parayı hemen ver.

- eli ağır: Yavaş iş gören.

- eli çabuk: Çabuk iş gören, hamarat (kimse).

- elinden iş çıkmamak: Çabuk iş yapamamak. 
- eli (eline) çabuk: Çabuk iş gören (kimse).

- gözünü kırpmadan: Uzun boylu düşünmeden, hemen, duraksamadan.

- kelle götürür gibi: Bir muştu ulaştıracakmış gibi çok hızlı koşarak.

- taban götürmek: Hizla gitmek.

- taban kaldırmak: bk. "taban götürmek"

- tabanları yağlamak: Hızlıca koşmak, kaçmak.

\section{Kalınlık-İncelik Ölçüsü Bildirenler}

- kol gibi: Çok kalın, aşırı kalın.

\section{Mesafe Ölçüsü Bildirenler}

- ağzına girmek: Çok yaklaşmak.

- bıçak sırtı: Çok yakın (aralık).

- bir boy gitmek: Aradaki mesafe boyunca gitmek.

- burnuna girmek: Birinin yanına çok yaklaşmak, birine çok sokulmak.

- burnundan ayrilmamak: Yanından gitmemek, uzaklaşmamak.

- burnunun dibi: Çok yakın.

- burun buruna gelmek: Beklenmedik bir anda karşılaşmak, birbirlerine çok yaklaşmak.

- el ermez, göz görmez: Bulunduğu yer çok uzak.

- eli ermemek: Uzakta olduğundan yetişememek.

- nazar yetişmek: Görülebilir mesafede olmak.

\section{Miktar Ölçüsü Bildirenler}

- ağızda sakız etmek: Bir şeyi tekrarlayıp durmak.

- ağza tat, boğaza (mideye) feryat: Miktarı çok az olan yiyecek.

- ağzında tükürüğ̈̈ kurumak: Bir şeyi defalarca tekrarlamak.

- analık eliyle vermek: Çok az vermek.

- baş başa bırakmak: Görüşmeleri için iki kişiyi yalnız bırakmak.

- baş başa kalmak: Bir şey konuşmak için yalnız kalmak isteyen kişilerin yanlarından başkaları gidip ikisi kalmak.

- baş başa (kafa kafaya) vermek: Birbirlerinin düşüncesinden yararlanmak üzere birkaç kişi toplanıp bir konuyu görüşmek.

- başı kalabalık olmak: Yanında iş dolayısıyla çok kişi bulunmak.

- baştan aşmak: Pek çok olmak, pek çoğalmak.

- bin bir ayak bir ayak üstüne: Herkesin ayakta olduğu kalabalık.

- bir ayağı bir yerde olmak: O yere s1k s1k gitmek.

- bir başına: Tek başına, yalnız. bk. "tek başına", "yalnız başına"

- devede kulak kabilinden (misalinden): Çok az.

- dişine değmek: Yiyecek pek az gelmek.

- el elde baş başta: Elde bulunan her şeyin tükendiğini anlatan bir söz.

- elde avuçta (ne varsa): Sahip olunan mal, para vb. her şey.

- eli aza varmamak: Bir şeyi çok alma veya verme alışkanlığında olmak.

- elinde avucunda nesi varsa: Parasının, varlığının hepsi.

- el ucuyla vermek: Çok az vermek.

- göz hakkı: Başkasında gördüğü şeye imrenmiş olacağı düşünülen kimseye o şeyden verilen pay.

- göz kararı: Ölçülerek ya da tartılarak değil, gözle oranlanarak belirlenen miktar.

- kan gövdeyi götürmek: Çok kan akmak, çok insan ölmek.

- kuru başına kalmak: Tek başına kalmak. 
- parmakla sayılmak: Çok az olmak.

- taban döşemek: Çok gidip gelmek.

- tek başına: Kendi kendine, yalnız olarak.

- yalnız başına: Kendi kendine, bir kendisi, tek başına.

\section{Para Ölçüsü Bildirenler}

- ayakbastı: Bir yere dışarıdan gelen insan veya eşyadan alınan vergi, toprakbastı.

- ayak teri (veya terliği): 1. Hizmet için bir yere gönderilen kimseye verilen ücret, ayak kiras1; yolluk, harcırah. 2. Bir haber veya eşya getirene emeğine karşıllk verilen para, ayak kirası.

- başının gözünün sadakası: Başa gelecek bir belayı savmak veya önlemek için yapılan bağış, özveri.

- bir eli yağda bir eli balda (olmak): Varlık ve bolluk içinde olmak.

- boğaz tokluğuna: Ücret verilmeden, yalnız karnını doyurarak.

- diş kirası: 1. Sarayda, zengin konaklarında iftardan sonra konuklara verilen armağan veya para. 2. Bir kimseye fazladan verilen para.

- elden ağza yaşamak: Günlük kazancı ancak gereksinimlerini karșılayacak kadar olmak.

- eli ağzına yetmemek: Kazancı geçimini karşılayamayacak kadar az olmak.

- tırnağı dibinde: Nakit.

\section{Renk Ölçüsü Bildirenler}

- Arap dilini çıkartmış gibi: rnk. Parlak kırmızı.

- beniz aldırmak: Benzi atmak, korkudan sararmak.

- beniz geçmek: Benzi solmak.

- benzi alınmak: enzi bozularak sararmak.

- benzi atmak (uçmak): Ansızın yüzünün rengi sararmak, solmak.

- benzi çalınmak: Yüzünün rengi değişmek.

- benzi kül gibi olmak: Yüzünden kan çekilmek, yüzü sararmak.

- benzi sararmak: Yüzünün rengi solmak.

- benzi uçmak: Yüzü sararmak.

- benzi ürpermek: Rengi atmak.

- benzinde kan kalmamak: Kansızlık sebebiyle yüzü sararmak.

- bet beniz gül gibi olmak: Kizarmak.

- bet beniz kalmamak: Yüzü sararıp solmak.

- beti benzi kireç kesilmek (atmak / solmak / uçmak / kül kesilmek): Herhangi bir sebeple kanı çekilip yüzü solmak.

- gözleri kan çanağına dönmek: Uykusuzluk, yorgunluk, ağlama, öfke vb. sebeplerle gözleri çok kizarmak.

- gözlerinin içine kadar kızarmak: Utancından yüzü çok kızarmak.

- gözü kan çanağı olmak: Çok ağlamaktan ya da uykusuzluktan gözleri kızarmış olmak. $b k$. "gözleri kan çanağına dönmek"

- kan çanağı gibi: Çok kızarmış göz.

• ölü gözü gibi: Çok sönük (1şık).

- turna gözü gibi: Duru sarı.

- tüyü bozuk: Sarışın veya saç rengi açık ve bozuk olan (kimse).

- yüzü kâğıt gibi (olmak): Kanı çekilip benzi solmak.

- yüzü mum gibi olmak: Benzi atmak, sararmak.

- yüzüne kan gelmek: Benzinin solgunluğu geçmek.

Uzunluk Ölçüsü Bildirenler 
- altı karış beberuhi: Çok kısa adam.

- bastı bacak: Bodur kimse.

- bir karış beberuhi: Çok kısa boylu kimse.

- boy pos yerinde: uzn. Uzun ve biçimli.

- boyu (boyunca) beraber: Kendi boyu kadar.

- mastı bacak: Bodur kimse.

- saçı topuklarını dövmek: Saçı çok uzun olmak.

\section{Zaman Ölçüsü Bildirenler}

- ağzı süt kokmak: Çok genç ve toy olmak.

- ayağını sürümek: Ölmek üzere olmak.

- ayağının tozu ile: Yoldan gelir gelmez, henüz dinlenmeden.

- ayağının tozunu silmeden: Henüz yoldan gelmişken.

- ayağı üzengide: Hemen yola çıkmak üzere olan.

- baş eldeyken: Ölmeden, yaşarken, sağken.

- beli bükülmek: Yaşl1lık yüzünden güçsüz kalmak, bir iş yapamayacak duruma düşmek.

- belini taş eylemek: İhtiyarlamak.

- bir ayağı çukurda olmak: 1. Yaşayacak çok az zamanı kalmış olmak. 2. Çok yaşlanmış olmak.

- bir ayağı kıyıda, bir ayağı kuyuda olmak: Son günlerini yaşıyor, ölümü yakın.

- bir ayağı üzengide olmak: Geziye çıkmak üzere olan.

- boyu bacadan mı aştı?: Yaş. Kızlar için, daha evlenecek yaşta değil.

- çiçeği burnunda (çamuru karnında): zmn. Bir iş ya da durumda henüz yeni olan.

- dünya gözüyle: Ölmeden önce.

- elden ayaktan düşmek (kesilmek): Yaşl1lık sebebiyle veya sağlığı büsbütün bozularak çalışamaz duruma gelmek.

- ele gelmek: Bebek kucağa alınacak kadar büyümüş olmak.

- eli kulağında: Nerede ise olacak, çok yakında olması beklenen.

- eline doğmak: Bir kişiyi doğduğundan beri tanımak.

- giderayak: Gitmek üzereyken, gitme anında.

- göbeğini kesmek: Birini çok eskiden beri tanımak, bilmek.

- göz açıp kapayıncaya kadar: Çok kısa bir zamanda.

- gözünün çapağını silmeden: Uyanır uyanmaz, çok erken.

- gözü toprağa bakmak: Ölümü yaklaşmış olmak.

- ilk ağızda: İlkin, en önce, ilk iş olarak.

- kaşla göz arası (arasında): Kimsenin sezmesine imkân vermeyecek kadar kısa bir zaman içinde, çok çabuk.

- kıl payı: Çok az (kalmak).

- parmak kaldı: Az kaldı, az kalsın, neredeyse.

- saç ağartmak: Bir işte uzun süre çalışmış olmak. bk. "saç sakal ağartmak"

- saçı başı ağarmak: Yaşlanmak.

- saçı bitmedik (yetim): Doğalı çok olmamış (yetim).

- saçına ak düşmek: Yaşlanmaya başlamak.

- saçına ak düşmek: Yaşlanmak.

- saçları iki türlü olmak: Yaşı ilerlemiş olmak.

- saç sakal ağartmak: Bir işte uzun y1llar çalışmış olmak. bk. "saç ağartmak"

- şeytan elini çekmiş: Uygunsuz bir iş yapacak veya kötülük düşünecek durumu olmayan çok yaşli kimse. 


\section{Sonuç, Tartışma ve Öneriler}

Türkiye Türkçesinde ölçü birimleri konusunda yapılan çalışmaların çoğunluğunun konusunu standart bir ölçü bildiren ve resmî olarak da ölçü kabul edilen ölçü birimleri oluşturmuştur. Bu konuda yapılan çalışmaların birbirlerinden ayrıldığı nokta genellikle ölçü birimlerinin kullanıldığı yüzyıllar olmuştur. Söz gelimi Divan şiirinde ölçü birimleri, Divânu Lugâti't-Türk'te ölçü birimleri, Osmanlı döneminde ölçü birimleri, Eski Türkçede ölçü birimleri şeklinde çalışmalar yapılmıştır ve bu çalışmaların hepsi standart ölçü birimlerini incelemiştir.

Türkiye Türkçesinde resmî olarak bir ölçü bildirmeyen ancak halk arasında bir ölçü gibi kullanılan bu tür ölçü bildiren ifadeler konusunda yapılan çalışmaların sayısının oldukça az olduğu görülmektedir. Bu türden ölçü birimlerini esas alan ilk çalışma, Orhan Şaik Gökyay tarafından yapılmıştır. Gökyay, "Halk Dilinde Ölçü Birimleri" adlı makalesinde, "genel ölçü adları, ağırlık ölçüleri, alan ölçüleri, miktar ölçüleri, uzunluk ölçüleri" olmak üzere beş ölçü türü belirlemiş ve bunların standart ölçü birimleri olmadığını, zamana ve mekâna göre değişiklik gösterdiğini vurgulamıştır. Mustafa Şenel, "Türkiye Türkçesi Ağızlarında Ölçü Birimleri” başlıklı makalesinde "ağırlık, derece, mesafe, miktar, ölçü, uzunluk, zaman" olmak üzere yedi ölçü türü belirlemiş ve bunlara Türkiye Türkçesi ağızlarından örnekler vermiştir. Şenel, ayrıca ölçü bildiren deyimlere de değinmiştir.

Salim Küçük, "Sözlük Birim Bir Unsur Olarak Türkçede Organ Adlarına Dayalı Ölçü Adları" adlı makalesinde tarihî Türk lehçeleri ve Türkiye Türkçesi ağızlarını esas alarak organ adları üzerinden oluşmuş ölçü birimlerini isim ve fiil başlıkları altında incelemiştir. Küçük, makalesinde ağırlık, alan, miktar ve uzunluk olmak üzere dört ölçü türünü esas almıştır.

Çalışmamızın konusu olan ölçü birimleri, Türkiye Türkçesinde insan bedeni esas alınarak oluşturulmuş ölçü birimleridir. Bunlar ya doğrudan organ adlarını kullanarak ya da organların gerçekleştirdiği bazı eylemleri esas alarak oluşturulmuş ölçü birimleridir. Bunların çoğunluğu standart bir ölçü bildirmeyen ancak standarta yakın ölçülerdir. Söz gelimi "bir avuç toprak" ifadesindeki miktar ölçüsü tahminîdir ve burada miktarı kişinin elinin boyutu belirler. Çeşitli eller tarafindan yapılacak böyle bir miktar ölçüsü elbette ufak tefek farklılıklar gösterecektir. Ancak ortalama el büyüklüğü çoğu kişide aynıdır. Buradaki ölçü birimi her ne kadar tahminî ise de yine de herkes tarafından bilinen ve kabul edilen standart ortalamaya yakındır.

Elde ettiğimiz malzeme, on bir ana ölçü türü esas alınarak sınıflandırıldı: Ağırlık, boyut, hız, kalınlık-incelik, mesafe, miktar, para, renk, uzunluk, yön, zaman. Çalışmamızda da açtı̆̆ımız ana ölçü türü başlıklarından da anlaşılacağ gibi ağırlık, miktar, mesafe, uzunluk bildiren ana ölçü türleri dışında "boyut, hız, kalınlık-incelik, para, renk ve yön" gibi özelliklerin de birer ölçü türü olarak kabul edilmesi gerektiği kanaatindeyiz. Bu kanaat, standart bir ölçü bildirmeyen, gündelik dilde çokça kullandığımız ölçü bildiren ifadelerde dil mantığı açısından kabul edilebilir bir yapı arzetmektedir. Söz gelimi "avuç" organı "bir avuç findık" ifadesinde nasıl miktar bildiren bir ölçü birimi olarak kullanılabiliyorsa "k1l" da "k1l testere" ifadesinde nesnenin k1l gibi ince olduğunu işaret ettiği için bir kalınlık-incelik ölçü birimi olarak kullanılabilir. Bu açıdan bakıldığında, yüzey yapıda bir ölçü ifadesi bulundurmayan bu türden ölçü birimlerinin, alışılagelmiş "ağırlık, mesafe, miktar, uzaklık, uzunluk, zaman" gibi sınıflandırmalardan başka "hız, kalınlık-incelik, para, renk ve yön" gibi ölçü türü sınıflandırmaları da esas alınarak değerlendirilmesi gereklidir.

İnsanın beş duyu organı en çok kullanılan ve en esaslı ölçme araçlanıdır. İnsanoğlu ölçümlerinin pek çoğunu bu beş duyu organı ile tecrübe etmekte, hatta bu ölçümleri dile yansıtırken de zaman zaman çeşitli organ adlarını kullanmaktadır. Bu türden organ adlarıyla yapılan ölçümler, bugün gündelik yaşamda en sık başvurulan bir pratik olarak dilde önemli bir yere sahiptir. Bu beş duyu üzerinden ifade edilen ölçü birimleri, her zaman aynı sonuçları vermez. İnsanın kendi bedeni üzerinden benzetme yapmak suretiyle oluşturduğu bu ölçü birimleri, elbette çok net, standart bir ölçüyü bildirmezler. Ancak genel geçer, tahminî bir ölçü birimi oluşturmak için de birebirdirler. Çünkü bu beş duyunun ve onun organlarının işleyişi, fizyolojik durumu ve boyutı kişiden kişiye 
farkl11kklar gösterebilir. Sağlıklı bir insan olsa bile bu beş duyunun her insandaki algı yetisi ve işlerliği farklıdır. Bazen benzetmelerde kendisine benzetilen kadar benzeyen varlığın da ne olduğu ölçüyü belirlemede önemli bir belirleyicidir. Söz gelimi bir patates için "kafam kadar" benzetmesi büyük olmayı ifade ederken televizyon için küçük olmayı bildirir.

Çalışmamızda elimizdeki malzemeyi sadece anlam açısından tasnif etmeye çalıştık. Bunu yaparken tespit ettiğimiz hususları şöyle özetleyebiliriz:

1. Antropometri sistemiyle oluşturulmuş ölçü birimlerinin çoğunda organ adları gerçek anlamıyla kullanılmıştır. "bir avuç findık", "iki adım yer" gibi örneklerde geçen organ adı ya da organın gerçekleştirdiği eylem adı somut bir gerçekliğe dayanmaktadır.

2. Organ adlarının doğrudan kullanılarak gerçek anlamları ile ölçü birimi oluşturulmasında bazı benzetme edatlarının yardımı da göz ardı edilemez: el kadar, kıl gibi vb.

3. Bir kısım organ adları gerçek anlamlarından uzaklaşarak yine organla bağıntılı olmak kaydıyla yan anlamlar kazanmaktadır. Özellikle yön bildiren ölçü birimlerinde bu durum açıkça görülmektedir. Söz gelimi "ağız, burun vb." organ adları, cansız varlıklar için ağız ve burun organlarına biçim olarak benzerliklerinden dolayı yön bildiren ölçü birimleri olarak kullanılmaktadır:

"ağız" in gerçek anlamı aşağıdaki gibidir:

ăglz: 1. Yüzde, avurtlarla iki çene arasında bulunan, ses çıkarmaya, soluk alıp vermeye yarayan ve besinlerin sindirilmeye başlandiğı organ. 2. Bu boşluğun dudakları çevreleyen bölümü.

Ancak yön bildiren bir ölçü birimi olarak kullanıldığında "ağız" organının özelliklerinden yola çıkılarak, biçimce benzetme yoluyla yan anlamları kazanmıştır. Kazanılan bu yan anlamlar sözkonusu organdan esinlenerek benzetme yoluyla yapıldıklarından, ağızın kendisinden bağımsız değildir.

ağız: 2. Kapların veya içi boş şeylerin açık tarafı. $\rightarrow$ bardağın ăgzl, şişenin ağzl vb. 3. Koy, körfez, liman vb. yerlerin açık tarafi. $\rightarrow$ körfezin ăgzı vb. 4. Uç, kenar. $\rightarrow$ uçurumun ăgzı $v b$.

4. Yan anlamların dışında "beli bükülmek, çiçeği burnunda, eli kulağında, göz açıp kapayıncaya kadar, gözü toprağa bakmak, saçı başı ăgarmak” vb. deyimlerin çoğu benzetme yoluyla veya müstakil cümleler şeklinde dolaylı yoldan ve tahminî bir ölçü bildirmektedir. Müstakil organ adları veya bu organların eylemlerinin tahminî bir ölçü birimi oluşturması hadisesine çok sayıda deyimde de rastlanılmaktdır. Bu yüzden çalışmamızda deyimleşmiş ölçü birimleri için de ayrı bir başlık açtık.

5. Organların yaptığı eylemlerden hareketle yapılan ölçü birimlerinde dikkat çekici bir husus bulunmaktadır. "at-, iç-, koş-, sık-" vb. fiilleri Türkiye Türkçesinde işlek bir fiilden isim yapma eki olan -ş+ ile ya da başka bir ekle değil yine bir fiilden isim yapma eki olan -(U/ I)m+ ekiyle yapılmaktadır. Bu fiillerin hep aynı yapım ekiyle isimleştirilip "at-ım, iç-im, koş-um, sık-ım” şekillerinin tercih edilmesi, onları birer ölçü birimi olarak sistemleştirme eğilimidir.

Açıklamalar: Bu makale Türkiye Türkçesinde Somut Bir Ölçü Bildiren İfadeler adlı doktora tezinden üretilmiştir.

\section{Kaynaklar}

Aksoy, Ö. A. (1997). Atasözleri ve deyimler sözlüğü I: Atasözleri sözlüğü. İstanbul: İnkılap Kitabevi.

Aksoy, Ö. A. (1997). Atasözleri ve deyimler sözlüğü II: Atasözleri sözlü̆̆̈̈. İstanbul: İnk1lap Kitabevi.

Aktunç, H. (2010). Türkçenin büyük argo sözlüğü (tanıklarıyla). İstanbul: Yap1 Kredi Yayınları.

Çakır, U. (2015). Türkiye Türkçesinde somut bir ölçü bildiren ifadeler. Doktora Tezi, Erciyes Üniversitesi, Sosyal Bilimler Enstitüsü, Kayseri. 
Gökyay, O. Ş. (1981). Halk dilinde ölçü birimleri. Türk Fokloru Araştırmaları, I(1), 41-48.

Küçük, S. (2019). Sözlük birim bir unsur olarak Türkçede organ adlarına dayalı ölçü adları. Karadeniz Araştırmalart, XVI(64), 647-669.

Önal, S. (2016). Antropometri ve spor üzerine. Ahi Evran Üniversitesi Sosyal Bilimler Enstitüsü Dergisi, II(2), 98-100.

Özyetgin, M. (2005). Orta zaman Türk dili ve kültürü üzerine incelemeler. İstanbul: Ötüken Yayınlar1.

Robinson, A. (2007). Ölçüler kitabı. İstanbul: NTV Yayınları.

Şenel, M. (2011). Türkiye Türkçesi ağızlarındaki ölçü birimleri. Karadeniz Araştırmaları, III(12), 8092.

Büyük Türkçe Sözlük. (2005). Türk Dil Kurumu Yayınları: Ankara. 


\section{Extended Abstract}

\section{Introduction}

Measuring is a behavior spread to every area of our lives, whether we are aware or not. Everything from abstract concepts to concrete beings has been influenced by measurement behavior, one of the basic tendencies of human beings. Two thousand five hundred years ago thinker Protagoras, "Man is the measure of everything," we think he meant this tendency.

Mankind has been tending to measure the assets and objects in life since the early ages. Of course, every community or tribe has developed a set of attitudes and attitudes that are the first in measurement in their geography, and has used tools that make measurements. However, these incompatible or non-standard traditional units of measure, which dominated much of human history, also created an endless confusion. As time progresses and technology and communication develop, most units of measure that are unique to societies are integrated into a common international system and universalized. Because this partnership has become a must for the healthy commercial and political relations between nations. As a result, the paintings drawn on the cave walls, the notch system, and the attempts of measurement such as the movements of the moon and the sun have been replaced by the measurement units adopted by a common standard all over the world since the modern centuries. Nevertheless, the measurement units created by the anthropometry system, which is one of the two main methods adopted by mankind even in the first centuries, maintain their place today as in the early ages. According to the anthropometry system, human beings experience many of these measurements with these five sensory organs, and sometimes they use various organ names to reflect these measurements to language. Measurements made with such organ names have an important place in language as the most common practice in daily life today.

The concept of measurement and measurement practices in almost every field of daily life have given many words to the language of that culture in every culture. These gains are formed either by individual words that express only one measure, or by any existing word gaining a semantic signifying measure.

Human beings are based on anthropometry in ancient times when technology did not develop. Anthropometry is a special science that deals with the dimensions of the human body. These units of measurement, which are created by analogy on human body, of course do not declare a very clear, standard one. However, general passages are also ideal for establishing a predictive measure. Such metaphors are still used in daily life, where measurement instruments and units of measurement are highly developed and even reduced to standards.

\section{Method}

The basis of our study is the measurement of what practices we are measuring in daily life, how these measures become experiences and become widespread in the society, while doing so, what are the characteristics of the entities we have chosen and how do they find their reflection in the language? In trying to answer this question through the material we obtained, the words related to the human body were taken as basis. The material was obtained by scanning the Great Turkish Dictionary, Derleme Dictionary and Tarama Dictionary. In our study, the estimated expression indicating a measure created by the system, anthropometry Turkish Turkey were classified in terms of meaning were identified.

We divided the material we obtained in our study into two main groups:

1. Units of measurement directly formed by organ names: 
ăgız, alın, avuç, aya, bacak, baş, beniz, bilek, boğaz, boy, bögü̈r, burun, çene, deri, dirsek, diş, diz, dudak, eğin, el, ense, geniz, göbek, göğüs, göz, kafa, karın, kelle, kemik, kll, kol, kucak, kulak, kulak memesi, meme, omuz, parmak, sirt, surat, ten, tırnak, topuk, tüy, yanak.

2. Units of measure based on the actions of the organs:

adım, atım, çağırım, çiynem, çimdik, çitmik, dizim, düzüm, doğram, dolam, erim, giyim, görüm, ışırım, içim, koşum, kulaç, sıkım, sıvam, sokum, suvarım, tadım, tıkım, tutam, yalamtık, yudum, yoğurum.

We classified these two main groups by giving eleven standard subheadings - type of measure -: 1.Weight Measure Reporters, 2. Dimension Measure Reporters, 3.Speed Measure Reporters, Thickness-Fineness Measure Reporters, Distance Measure Reporters, Quantity Measure Reporters, Money Measure Reporters, Color Measure Reporters, Length Measure Reporters, Direction Measure Reporters, Time Measure Reported cost.

Even though there is no material to exemplify some of the subheadings, we still gave the subheading in order not to disturb the standard classification in both main groups.

\section{Results}

In most of the bodies have created units with Turkey in the Turkish system is used with a real sense of anthropometry. Some of the organ names move away from their real meaning and gain side meanings provided that they are connected to the organ again. Apart from the semantics, most of the idioms express a predictive measure by analogy or indirectly in the form of individual sentences. In the use of some organ names as a unit of measure, the place of argon cannot be denied.

\section{Discussion and Suggestions}

All these explanations show that the concept of measurement has taken its place in the language through concretization in human life and has a great place. The lexical reflections of the measure in all languages are the most important evidence of this inclination. When the units of measurement created in this way are examined in terms of meaning and structure, it is seen that they have made a tremendous contribution to Turkish. 